\title{
The Impact of Social Capital on FDI in Georgia
}

\author{
Natia Aghladze \\ Ivane Javakhishvili Tbilisi State Universtity \\ Faculty of Economics and Business
}

\begin{abstract}
FDI brings capital, innovation exchanges and new employments and administration aptitude. In numerous nations, FDI inflow is lower than anticipated. In spite of the inclination for more extensive large scale level examinations of the particular social developments inside which financial exercises happen, a considerable measure of national-level investigations of the determinants of outside contributed firms have given careful consideration to the parts played by social capital and its unexpected incentive in influencing remote direct venture inflows. Drawing on the rationale of social capital and institutional hypothesis, this article looks to offer a correlative clarification of FDI by inspecting experimentally the national-level effects of social capital (trust and affiliated action) on FDI and the directing part of administrative quality in its connections. FDI is the essential part for an open and fruitful global monetary framework and a noteworthy instrument for improvement. In this condition, the paper looks at the advantages of FDI as a key segment for fruitful and feasible financial development and as a piece of a strategy to social change. The point is to feature the most vital channels through which FDI makes a huge and uncommon effect on the monetary advancement of the host nations.
\end{abstract}

Keywords: FDI, Social capital, Social trust, Host country, Location factor

\section{Introduction}

It has just been realized that the expanding advantages of FDI for the host nation can be huge, including human capital arrangement bolster, upgrade of focused business condition, commitment to global exchange joining and change of big business improvement. Also, more remote than monetary advantages FDI can help the change of condition and social condition in the host nation by migrating "cleaner" innovation and controlling to all the more socially capable corporate arrangements. ${ }^{1}$ Multinational ventures have turned out to be one of the key drivers of the world economy and their significance keeps on developing far and wide. Today, creating nations represent very nearly $33 \%$ of the worldwide supply of internal FDI, contrasted with marginally more than one fifth in 1990. This paper researches the significance of social capital in conjunction with the regular area factors that are known to impact the area choices of multinational firms inside Georgia. "Trust and Norms" part of social capital affects locational choices than does the "Interpersonal organization" segment. We will survey the nations what are described by an abnormal state of "Trust and Norms" draw in more information based FDI firms than those with bring down levels of trust and standards. What's more, positive agglomeration externalities are all the more capable in locales with a larger amount of trust and standards. Another critical aftereffect of our investigation is the revelation that the areas with high joblessness levels and union exercises are less appealing to outside speculators. In view of the outcomes, we reason that measures that reinforce the trust and standards segment of social capital ought to be cultivated alongside conventional cost-sparing strategies, which are utilized to draw in FDI in Georgia.

\section{Social Capital - Key to Success}

Social capital may be defined as those resources inherent in social relations which facilitate collective action. Social capital resources include trust, norms, and networks of association representing any group which gathers consistently for a common purpose. A norm of a culture high in social capital is reciprocity, which encourages bargaining, compromise, and

\footnotetext{
1 Selma K. (2013) The Effects of FDls for Host Country's Economy,
} 
pluralistic politics. Another norm is belief in the equality of citizens, which encourages the formation of cross-cutting groups. 1 "Social capital" may first have appeared in a book published in 1916 in the United States that discussed how neighbors could work together to oversee schools. Author Lyda Hanifan referred to social capital as "those tangible assets, that count for most in the daily lives of people: namely goodwill, fellowship, sympathy, and social intercourse among the individuals and families who make up a social unit". That gives some sense of what's meant by social capital, although today it would be hard to come up with a single definition that satisfied everyone. For the sake of simplicity, however, we can think of social capital as the links, shared values and understandings in society that enable individuals and groups to trust each other and so work together.

There is much debate over the various forms that social capital takes, but one straightforward approach divides it into three main categories:

Bonds: Links to people based on a sense of common identity ("people like us") - such as family, close friends and people who share our culture or ethnicity.

Bridges: Links that stretch beyond a shared sense of identity, for example to distant friends, colleagues and associates.

Linkages: Links to people or groups further up or lower down the social ladder. The potential benefits of social capital can be seen by looking at social bonds. Friends and families can help us in lots of ways - emotionally, socially and economically.

Social capital is defined by the OECD as "networks together with shared norms, values and understandings that facilitate co-operation within or among groups". In this definition, we can think of networks as real-world links between groups or individuals. Think of networks of friends, family networks, networks of former colleagues, and so on. Our shared norms, values and understandings are less concrete than our social networks. Sociologists sometimes speak of norms as society's unspoken and largely unquestioned rules. Norms and understandings may not become apparent until they're broken. Values may be more open to question; indeed, societies often debate whether their values are changing. And yet values such as respect for people's safety and security - are an essential linchpin in every social group².

\section{Importance of FDI}

FDI is an integral part of an open and effective international economic system and a major catalyst to development. The benefits of FDI do not accrue automatically and evenly across countries, sectors and local communities. National policies and the international investment architecture matter for attracting FDI to a larger number of developing countries and for reaping the full benefits of FDI for development. The challenges primarily address host countries, which need to establish a transparent, broad and effective enabling policy environment for investment and to build the human and institutional capacities to implement them. Developed countries can facilitate developing countries' access to international markets and technology, and ensure policy coherence for development more generally; use overseas development assistance to leverage public/private investment projects; encourage non-OECD countries to integrate further into rules-based international frameworks for investment. ${ }^{3}$

Creating nations, rising economies and nations experiencing significant change have come progressively to consider FDI to be a wellspring of financial improvement and modernization, wage development and work. Nations have changed their FDI administrations and sought after different arrangements to draw in speculation. They have tended to the issue of how best to seek after local approaches to expand the advantages of remote nearness in the household economy. The general advantages of FDI for creating nation economies are much recorded. Given the fitting host-nation approaches and a fundamental level of improvement, a prevalence of studies demonstrates that FDI triggers innovation overflows, helps human capital arrangement, adds to global exchange reconciliation, makes a more focused business condition and upgrades venture advancement. These add to higher monetary development, which is the most powerful apparatus for reducing destitution in creating nations. In addition, past the entirely monetary advantages, FDI may help enhance

\section{G. David Garson, (2006) Social Capital Theory, Harvard University Press}

2 OECD Insights: What is social capital? https://www.oecd.org/insights/

3 OECD, (2002), FDI for Development,

https://www.oecd.org/investment/investmentfordevelopment/1959815.pdf 
ecological and social conditions in the host nation by, for instance, exchanging "cleaner" innovations and prompting all the more socially dependable corporate strategies.

Most experimental examinations infer that FDI adds to both factor efficiency and salary development in have nations, past what residential venture regularly would trigger. It is more troublesome, in any case, to survey the greatness of this effect, not minimum since huge FDI inflows to creating nations regularly agree with abnormally high development rates activated by irrelevant components. A few analysts have discovered proof of swarming out, while others reason that FDI may serve to expand local speculation.

\section{Social Capital and FDI - The Truth Behind}

In this section, we will discuss that host countries' social capital in the form of trust and associative activities positively affect FDI inflow. We base these relationships on the premise that a society's social capital endowment plays a determining role in shaping the investment environment. Social capital is considered multidimensional. It is conceived as associative participation ${ }^{1}$, norms of civic behavior, ${ }^{2}$ perceived corruption, ${ }^{3}$ trust ${ }^{4}$. Relating to our research interest in FDI inflow as an economic activity, we focus specifically on trust and associative activity and regulatory quality since the social embeddedness of economic activities is the defining characteristic ${ }^{5}$ that can shape the perception and behavior of the economic agents and the regulative dimension as the key determinant of high quality-institution 6 is particular relevant to the primary concerns of foreign investors regarding rule implementation and legal protection of proprietary assets. Extending reasoning from the social capital perspective, we argue that given other favorable conditions, national markets would present themselves as ideal markets for FDI that is embedded in a congenial social fabric that is built on trust and associational activities.

Trust is a key component of social construction ${ }^{7}$ and is a "manageable act of faith in people, relationships and social institutions" 8 . It has long been considered an essential component for most forms of social exchange ${ }^{9}$. Viewed from the research on the impacts of social capital on economic development and the multiple lines of research documented in the international business literatures, we draw out two particular benefits of trust in its positive impacts on FDI: cooperative business environment and reduction of transaction costs. First, FDI activities are embedded in host countries' economic and social contexts, unavoidably interacting with local business, government, and individuals. Because FDI involves extensive social exchanges through managing business relationships with local partners and employees, suppliers and buyers, it follows that having an honest and trustworthy relationship is critical for successful investment. In selecting national markets for foreign investments, multinational enterprises as agents of FDI would prefer national markets exhibiting cooperative milieu that potentially enhances the easiness to build and foster beneficial business relationships. Prior studies show that a society with a high "trust culture" where individuals tend to hold positive attitudes towards each other ${ }^{10}$, is easier to enable cooperative behavior ${ }^{11}$ that leads to economic gains ${ }^{12}$. Conversely, it is also found that when a society is

\footnotetext{
1 Putnam, R. (1993) Making Democracy Work: Civic Traditions in Modern Italy. Princeton: Princeton University Press

2 Paxton, P. (1999) 'Is Social Capital Declining in the United States? A Multiple Indicator Assessment', American Journal of Sociology 105: 88-127.

${ }^{3}$ Svendsen, G. T. (2004) Political Economy of the European Union: Institutions, Policy and Economic Growth, Cheltenham, UK: Edward Elgar

${ }^{4}$ Knack, S. and Keefer, P. (1997). Does Social Capital Have an Economic Payoff? A Cross-Country Investigation, The Quarterly Journal of Economics (November): 1251-1288.

${ }^{5}$ Granovetter, M. (1985) 'Economic Action and Social Structure: the Problem of Embeddeness', American Journal of Sociology 91(3): 481-510.

${ }^{6}$ Kaufmann, D, Kraay, A, and Zoido-Lobaton, P, (1999). Governance Matters, World Bank Policy Research Working Paper 2196 , Washington DC

${ }^{7}$ Child, J. and Mollering, G. (2003). Contextual evidence and active trust development in the Chinese business development, Organization Science, 14, 69-80.

8 Shepard, B.H. and Sherman, D.M. 1998. The grammars of trust: A model and general implications. Academy of Management Review, 22: $422-437$.

${ }^{9}$ Blau, P. M. (1964) Exchange and Power in Social Life, New York: Wiley.

10 Das, T. K., \& Teng, B. S. (2000). Instabilities of strategic alliances: An internal tensions perspective. Organization Science, 11: $77-$ 101.

11 Gambetta, D.J. (1988). Can we trust trust?. In Trust. D.G. Gambetta (ed.), Basel Blackwell, New-York, 213-237.

12 Miller G. J. (1992). Managerial Dilemmas: The Political Economy of Hierarchies. New York: Cambridge Univ. Press.
} 
pervaded by distrust, cooperative arrangements are unlikely to emerge. Second, the high level of trust in a national market offers a favorable business environment that helps curb transaction costs by reducing monitoring costs. ${ }^{1}$

Early research showed that trust facilitates successful negotiations, ${ }^{2}$ promotes adaptive organizational forms, reduces harmful conflict and transaction costs ${ }^{3}$, and encourage compliance with business rules and norm that results in costs associated with formal control in the organization. ${ }^{4}$ Additionally, high levels of trust in a society makes possible the reduction of transaction costs in markets where there is high information ambiguity due to the institutional void. ${ }^{5}$

Both Putnam in 1933 and Coleman in 1990 refer to associative activity as another manifestation of social capital. It is a social network activity that provides individuals with contact opportunities in organizations of various backgrounds and professions. Prior studies have shown that the presence of dense network of association in a country can help increase entrepreneurial and other economic activities. Early studies indicated that the entrepreneur's professional relationship with influential people helped significantly in locating capital for project funding. ${ }^{6}$ Putnam in 1993 attributed the economic success and government efficiency of northern Italy partly to its richer associational life. Evidence documented that owners of small businesses used their contacts in organizations such as Chamber of Commerce and Small Business Federations and more informal organization to provide a source of useful ideas and business relationships ${ }^{7}$. Consistent with the resource dependency theory, ${ }^{8}$ studies of interlocking directorates showed that board member that belong to a variety of external organizations and associations help to link firms within a society to their external environment thereby providing access to novel information and other critical resources. Along these same lines, Carroll and Teo in 1996 found that the widely dispersed managerial social networks were associated with higher accessibility to resources.

The positive impact of associative activity offers benefits to foreign investors in many ways. First, a national market possessing dense association among individuals offers a valuable alternative source of market information. Foreign investors tend to suffer "liability of foreignness" that they bear the risks in foreign market without proper and timely access to local market information, ${ }^{9}$ thus, accessing market information is critical for them. A market characterized with extensive associative activity is attractive since it offers alternative informal access to local market information in addition to other formal channel of information. The second benefit is that associative activities represent valuable social resources. A society with a high level of associative activity presents itself with richer relational capital. The high level of associative activity can benefit foreign investors by offering easy access to this distinct social resource that may potentially facilitate the identifying talents, advertising products and services through mouths of words.

The impact of regulatory quality on the relationship between trust and FDI Regulatory institutions are clusters of rules and resources that are sustained across time and space within and among social systems. ${ }^{10}$ It is one of the three keys 'pillars' of social institutions..$^{11} \mathrm{~A}{ }^{12}$ well-functioned high-quality regulatory environment exists when rules and laws are formulated and are effectively enforced to ensure both the stability of economic transactions and order of a society. High-quality regulatory systems affect the social capital effects on FDI by providing the basis for the development of social capital. Though economic exchanges are embedded in reciprocal social relations, these exchanges cannot rely exclusively on the

\footnotetext{
${ }_{1}^{1}$ Fukuyama, F. (1995b). Social Capital and the Global Economy: A Redrawn Map of the World, Foreign Affairs,

2 Ross, W. H., \& Weiland, C. (1996). Effects of interpersonal trust and time pressure on managerial mediation strategy in a simulated organizational dispute. Journal of Applied Psychology, 81(3), 228-248.

${ }^{3}$ Meyerson D, Weick K, Kramer RM. (1996). Swift trust and temporary groups, in Kramer, M. and Tyler, T. R. (eds.), Trust in Organizations. Thousand Oaks, CA: Sage. 166-195.

${ }^{4}$ Adler, P. Kwon, S. (2002). Social Capital: Prospects for a New Concept. The Academy of Management Review, 27, No. 1pp. 17-40.

${ }^{5}$ Khanna, T. and Palepu, K. (2000). The future of business groups in emerging markets: Long run evidence from Chile, Academy of Management Journal, 41 (3): 260285.

6 Tyebjee, T, Bruno, A (1984) A Model of Venture Capitlaist Investment Activity, Management Science, 39, 9, 1051

${ }^{7}$ Chell, E., Baines, S (2000). Networking, entrepreneurship and microbusiness behavior, Entrepreneurship \& Regional Development, 12 , No. 3, $195-215$

${ }^{8}$ Salancik, G, Pfeffer, J (1978), A Social Information Processing Approach to Job Attitudes and Task Design, Administrative Science Quarterly, 23, 224

${ }^{9}$ Zaheer, S. (1995). Overcome the Liability of Foreigness,. Academy of Management Journal 38(2): 341-363.

10 Giddens, A. (1984). The Constitution of Society: Outline of the Theory of Structuration. Berkeley: University of California Berkeley. 11 Scott, W. and Meyer, J. (1991) 'The Organization of Societal Sectors: Propositions and Early Evidence', in W. Powell and P. DiMaggio (eds.) The New Institutionalism in Organizational Analysis, Chicago: University of Chicago Press, pp. 108-142.

12 Williamson, O.E. (1993). Calculativeness, trust and economic organization, Journal of Law and Economics, 36, 453-486.
} 
social resources, since weak regulative environment gives rise to the potential of opportunistic behavior that constitutes uncertainty for social and economic exchanges.

In a weak regulatory environment, distrust is likely to occur and institutional environment with low regulatory quality cannot effectively contain opportunistic behavior that undermines the value of social capital. However, the high regulatory quality ensures the stability and formation of social capital that is conducive to the economic exchanges, because it constitutes the institutional condition that deters the possible breach of trust resulting from opportunistic behavior, whereby the benefits of social capital to the economic endeavors such as FDI can be enhanced. Hence, the regulatory system as a key component of social institutions can act as broad supports for the critical mass of trust, ${ }^{1}$ and amplify the general benefits of social capital such as the protection of individuals' rights and property. ${ }^{2}$ The recent work by Zaheer and Zaheer (2006) and Arino, Torre, and Ring (2001) also propose the conditioning role of institution in the effects of social capital in terms of building trust and relational quality of partners in international alliances. In the same vain, Bhardwaj et al. (2007) showed the contingent value of trust on uncertainty avoidance in FDI determinants.

\section{FDI and Social Capital: Evidence from Georgian Reality}

Georgia is situated amongst Asia and Europe and involves a land territory of 69,700 sq. km. It neighbors Turkey toward the southwest, Azerbaijan toward the east, Russia toward the north and Armenia toward the south. Georgia empowers outside exchange and venture, and laws enable nonnatives to buy organizations and property, repatriate income and benefits, and get pay if property is nationalized. Remote undertakings and people are allowed to claim up to $100 \%$ outside responsibility for capital of Georgian organizations. There are a few restrictions on the exercises that might be directed, in any case, and remote interest in the resistance and security parts is not allowed. Georgia offers motivators for organizations situated in free industrial zones (FIZs), and for substances built up as an International Financial Company, Free Warehouse Enterprise or International Enterprise. The administration keeps up a free gliding and uninhibitedly convertible money, the Georgian Lari (GEL).

Georgia is an individual from NATO's Partnership for Peace Program and is effectively attempting to join NATO and the European Union. Georgia is additionally an individual from the United Nations, the OSCE, and GUUAM (Union of Georgia, Ukraine, Uzbekistan, Azerbaijan, and Moldova) and an onlooker in the Council of Europe. Georgia was once in the past an individual from the CIS (Commonwealth of Independent States). Due to the August 2008 clash with Russia, Georgia formally advised the CIS on 18 August 2008 of its aim to pull back from the association, and that withdrawal happened on 18 August 2009. Be that as it may, Georgia's Ministry of Foreign Affairs has said it will maintain all exchange and arrangement understandings made amongst Georgia and kindred CIS nations. Georgia has an unhindered commerce administration with individuals from CIS including Armenia, Azerbaijan, Kazakhstan, Turkmenistan, Uzbekistan and Ukraine. This outcomes in obligation unhindered commerce of merchandise and ventures. $40 \%$ of Georgia's fares go to CIS nations, and these nations represent $39 \%$ of Georgia's remote exchange turnover. On 18 December 2002, the GUUAM (Georgia Ukraine-Uzbekistan-Azerbaijan-Moldova) unhindered commerce assention was approved by the Georgian Parliament, the objective of which is to make ideal exchange conditions and to reinforce monetary connections among the part nations. The consent to shape a facilitated commerce zone was come to at the GUUAM Presidents' Summit in July 2003 in Yalta. Uzbekistan has since left the facilitated commerce zone. ${ }^{3}$

\footnotetext{
1 Sitkin SB. (1995). On the positive effects of legalization on trust, Research in Negotiation and Organization. 5, 185.217

2 Fukuyama, F. (1995b). Social Capital and the Global Economy: A Redrawn Map of the World, Foreign Affairs,

${ }^{3}$ Doing Business and Investing in Georgia, 2013 


\section{Graph 1. FDI Flow in Georgia in USD}

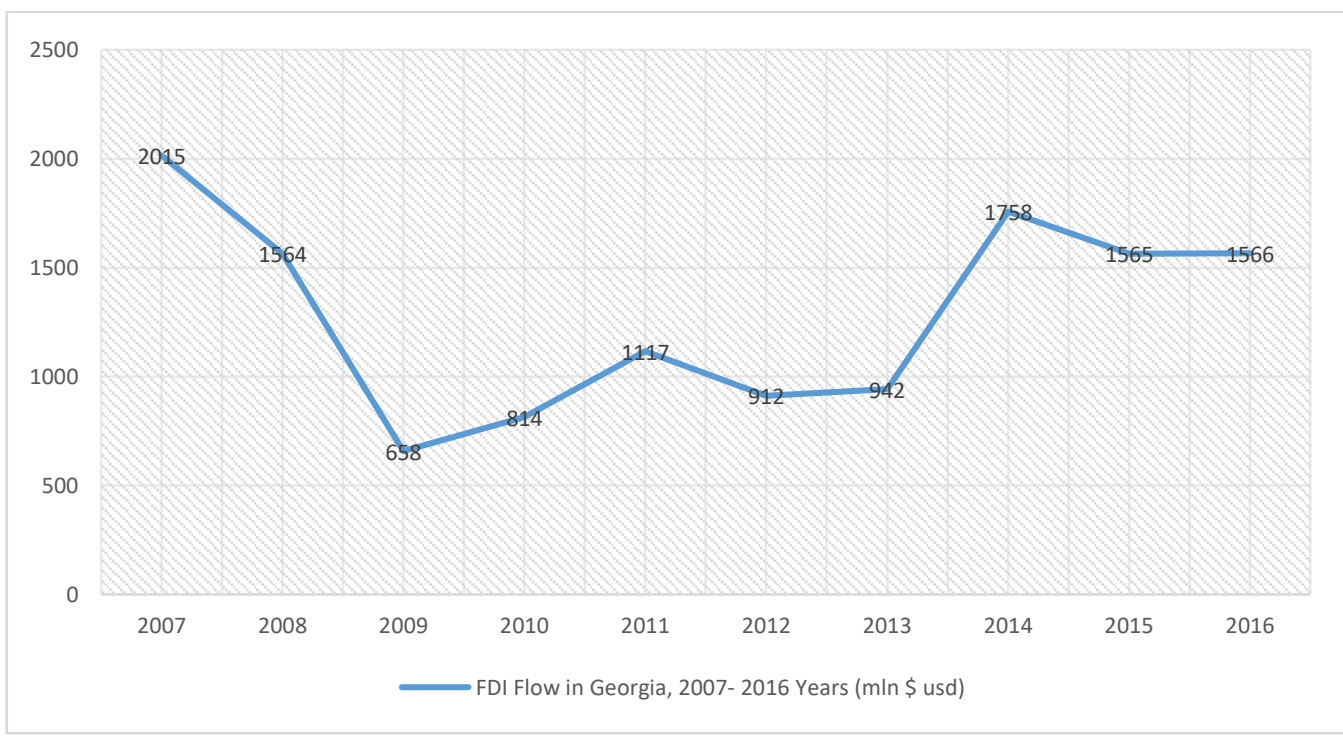

Source: National Statistics Office of Georgia, http://geostat.ge/index.php?action=page\&p_id=2231\&lang=eng

As should be obvious at diagram 1, FDI stream pay is not steady in Georgia. This reality can be clarified by the social capital hypothesis. As noted over, the photo of social capital in Georgia is blended: Georgia displays high degrees of holding social capital, of trust and of coordinated effort inside firmly weave gatherings. Georgians are liberal in their solidarity between each other, and most Georgians have given and got assistance from family, companions or neighbors, regularly putting the necessities of others before their own. The nation's well-known cordiality features another part of being open and inviting to outsiders: the information demonstrates that Georgians have uplifting dispositions to different nationalities, keeping up great perspectives towards Russians, Abkhaz and Ossetians - even specifically after the August 2008 clash. Whenever required, gatherings can shape - among neighbors or agriculturists, for instance - to settle an especially squeezing issue. Beside this, nonetheless, Georgia still has low levels of spanning social capital - especially of the sort that encourages more efficient co-operation between relative outsiders. Most unmistakably, Georgia has low levels of enrollment in formalized affiliations. As indicated by information from the World Value Surveys, Georgia positions amazingly low in contrast with a wide associate gathering of changing nations. Under five percent of the populace participates in affiliations or other formalized city movement and there are couple of enrollments based relationship in the nation up until this point.

The most visually striking manifestation of the lack of collaboration in Georgia is in housing. Many travelers remark how Tbilisi's neatly-appointed apartments contrast sharply with the dark, often semi-derelict communal areas found beyond their steel doors and the crumbling concrete of the building's foundations. This is not just a matter of poverty, since the same buildings may have stately SUVs parked in their courtyard. ${ }^{1}$ While occupants may team up to settle vexing issues, they regularly neglect to address substantive auxiliary issues in the very structures they share, to the disservice of all. There are, as such, couple of regions of financial, political and social life that are not influenced by low levels of formalized joint effort. While the low level of crossing over social capital denies the nationals of Georgia of noteworthy financial, social and social advantages, it likewise represents a critical test to fair improvement - for governments, notwithstanding when completely self-intrigued, can appreciate an advantageous association with the lively respectful society and flourishing monetary circles that broad joint effort makes conceivable. Proficient relationship, for instance, can retain broad administrative obligations, as they do in numerous Western nations, leaving basic leadership and its conflicts with bunches that are learned and influenced. All the more extensively, composed gatherings can turn into a transmission instrument for

${ }^{1}$ An Assessment of Social Capital in Georgia, 2011, Caucasus Research Resource Centers 
conveying nationals' worries, and would thus be able to empower the legislature to be more responsive. In these ways, government can decline some of its own issues to others for them to tackle. The low level of connecting social capital likewise makes an issue for benefactors and their projects. Different reasons, numerous improvement intercessions either require or even expect a noteworthy level of joint effort. The determination of a few issues -, for example, the change of instructive projects - requires broad information and associate surveys. In different cases, picks up in profitability call for foundational coordinated effort in sharing venture and support costs. In these cases, what may look like evident automatic plans may waver, since joint effort is harder to accomplish and considerably harder to keep up than initially foreseen. Advancement experts over and again portrayed in interviews how the aftereffects of specific projects had been frustrating on the grounds that individuals had neglected to draw in and work together. This circumstance has terrible impact of FDI and the low levels of connecting social capital are subsequently an issue that should be completely comprehended and figured into any arranging.

The nature of the "match" between outside administration rehearses and the host nation workforce might be a vital thought for advancement arrangement. For instance, serious preparing rehearses are probably going to be transferable crosswise over national limits, yet the particular sorts of social capital venture that enhance the profitability of the Georgian workforce may not be similarly compelling in other host nation settings.

\section{Conclusion}

Grounded in social capital and institutional hypothesis, this examination embarks to widen the logical system of FDI by inspecting the impacts of social capital measured by trust and acquainted movement, and the unexpected impacts of administrative quality. By and large, the consequences of the factual tests bolster the proposed speculations that, everything else equivalent, social capital measured by trust and affiliated movement are critical determinants of FDI inflow and that their belongings are additionally fortified by high administrative quality. Taken together, our discoveries propose that the nearness of rich social capital in a nation manage the cost of its both focused and relative points of interest to pull in outside ventures. It additionally supplements the current examination by Bhardwaj et al. (2007) by affirming positive connections amongst FDI and trust and expands their work by offering an administrative quality based possibility clarification of social capital. Our discoveries propose that social capital epitomized in abnormal state of trust and cooperative movement in a general public encourages social trade by decreasing the requirement for tedious and exorbitant observing, and in this way makes it feasible for financial trades more productive in a more ideal business condition that pulls in remote speculators. Administrative organizations of a country are a basic part of institutional situations. Notwithstanding the immediate impacts, our discoveries demonstrate that a fantastic administrative condition in a country offering a straightforward and decide based business condition that protections and improves the advantages of social capital in drawing outside venture inflow. This finding gives new experimental confirmation to the dispute that nonappearance of free legal frameworks and private lawful administrations (North, 1990) normally postures dangers to remote financial specialists because of the nearness of open seizure risks (Delios and Henisz, 2000). By setting up the connection between social capital and foundation condition, and FDI, this paper adds to the current FDI writing by offering a corresponding viewpoint to the clarification of FDI. Social capital as 'the magic that binds society' is the 'missing connection' in clarifying the improvement (Grootaert, 1998; Bebbington et al. 2002) all in all and its part on the planet wonder of FDI has been essentially left unattended in IB inquire about in particular. Filling in this hole, our examination improves our insight about the part of social capital plays in influencing FDI inflows past the supremacy of monetary reason. Our examination additionally expands our comprehension of the FDI impacts of social capital by propelling an unforeseen point of view, predictable with the unexpected viewpoint of social capital proposed by Burt (1997). This possibility point of view major to assisting the hypothesis advancement (Venkatraman, 1989) demonstrates that incorporating national administrative quality into the investigation of a two-variable relationship lessened the potential for deceiving derivations and allowed a "more exact and particular comprehension" (Rosenberg, 1968, p. 100) of the first two-variable relationship. Along these lines, our outcomes shed new light on the parts of administrative condition as an arbitrator that condition the connection between social capital and FDI and add corresponding clarifications to the current FDI writing that is fundamentally secured in the rationales of financial aspects.

\section{References}

[1] Adler, P. Kwon, S. (2002). Social Capital: Prospects for a New Concept. The Academy of Management Review, 27, No. 1pp. 17-40.

[2] An Assessment of Social Capital in Georgia, 2011, Caucasus Research Resource Centers 
[3] Blau, P. M. (1964) Exchange and Power in Social Life, New York: Wiley.

[4] Chell, E., Baines, S (2000). Networking, entrepreneurship and microbusiness behavior, Entrepreneurship \& Regional Development, 12, No. 3, $195-215$

[5] Child, J. and Mollering, G. (2003). Contextual evidence and active trust development in the Chinese business development, Organization Science, 14, 69-80.

[6] Das, T. K., \& Teng, B. S. (2000). Instabilities of strategic alliances: An internal tensions perspective. Organization Science, 11: 77-101.

[7] Doing Business and Investing in Georgia, 2013

[8] Fukuyama, F. (1995b). Social Capital and the Global Economy: A Redrawn Map of the World, Foreign Affairs,

[9] G. David Garson, (2006) Social Capital Theory, Harvard University Press

[10] Gambetta, D.J. (1988). Can we trust trust?. In Trust. D.G. Gambetta (ed.), Basel Blackwell, New-York, 213-237.

[11] Giddens, A. (1984). The Constitution of Society: Outline of the Theory of Structuration. Berkeley: University of California Berkeley.

[12] Granovetter, M. (1985) 'Economic Action and Social Structure: the Problem of Embeddeness', American Journal of Sociology 91(3): 481-510.

[13] Kaufmann, D, Kraay, A, and Zoido-Lobaton, P, (1999). Governance Matters, World Bank Policy Research Working Paper 2196, Washington DC

[14] Khanna, T. and Palepu, K. (2000). The future of business groups in emerging markets: Long run evidence from Chile, Academy of Management Journal, 41 (3): 260285.

[15] Knack, S. and Keefer, P. (1997). Does Social Capital Have an Economic Payoff? A Cross-Country Investigation, The Quarterly Journal of Economics (November): 1251-1288.

[16] Meyerson D, Weick K, Kramer RM. (1996). Swift trust and temporary groups, in Kramer, M. and Tyler, T. R. (eds.), Trust in Organizations. Thousand Oaks, CA: Sage. 166-195.

[17] Miller G. J. (1992). Managerial Dilemmas: The Political Economy of Hierarchies. New York: Cambridge Univ. Press.

[18] OECD Insights: What is social capital? https://www.oecd.org/insights/

[19] OECD, (2002), FDI for Development: https://www.oecd.org/investment/investmentfordevelopment/1959815.pdf

[20] Paxton, P. (1999) 'Is Social Capital Declining in the United States? A Multiple Indicator Assessment', American Journal of Sociology 105: 88-127.

[21] Putnam, R. (1993) Making Democracy Work: Civic Traditions in Modern Italy. Princeton: Princeton University Press

[22] Ross, W. H., \& Weiland, C. (1996). Effects of interpersonal trust and time pressure on managerial mediation strategy in a simulated organizational dispute. Journal of Applied Psychology, 81(3), 228-248.

[23] Salancik, G, Pfeffer, J (1978), A Social Information Processing Approach to Job Attitudes and Task Design, Administrative Science Quarterly, 23, 224.

[24] Scott, W. and Meyer, J. (1991) 'The Organization of Societal Sectors: Propositions and Early Evidence', in W. Powell and P. DiMaggio (eds.) The New Institutionalism in Organizational Analysis, Chicago: University of Chicago Press, pp. 108-142.

[25] Selma K. (2013) The Effects of FDIs for Host Country's Economy,

[26] Shepard, B.H. and Sherman, D.M. 1998. The grammars of trust: A model and general implications. Academy of Management Review, 22: 422-437.

[27] Sitkin SB. (1995). On the positive effects of legalization on trust, Research in Negotiation and Organization. 5, 185.217

[28] Svendsen, G. T. (2004) Political Economy of the European Union: Institutions, Policy and Economic Growth, Cheltenham, UK: Edward Elgar

[29] Tyebjee, T, Bruno, A (1984) A Model of Venture Capitlaist Investment Activity, Management Science, 39, 9, 1051

[30] Williamson, O.E. (1993). Calculativeness, trust and economic organization, Journal of Law and Economics, 36, 453-486.

[31] Zaheer, S. (1995). Overcome the Liability of Foreigness,. Academy of Management Journal 38(2): 341-363. 